\title{
Pre-epidemic preparedness and the control of Lassa fever in Southern Nigeria
}

\author{
Adebimpe Wasiu Olalekan
}

\begin{abstract}
The outbreak of Viral Haemorrhagic Fevers (VHF) in the West African sub region in recent times had negative consequences on the health systems, international travels, movements and trades. Nigeria is still battling with a significant spread of Lassa Fever (LF) outbreak. The country seems not to have learnt from past epidemics most especially the 2014 Ebola Virus Disease (EVD) outbreak. After the declaration of Nigeria EVD free, most control arsenals were relaxed, isolation and quarantine structures were dismantled and preventive efforts such as provision of Personal Protective Equipments (PPE) for the use of the vulnerable health care workers were not sustained.

Several search engines were used in surfing the internet while looking for literatures and systematic reviews on the epidemiology and control of Lassa fever in the West African sub-region, and narrowing down the search to Nigeria. This review presented findings from past outbreaks of Lassa fever in Nigeria and the control strategies adopted, including a review of several researches on the subject matter. Author also presented a framework of epidemic disease control for Lassa fever and other VHFs in line with WHO recommendations: It was observed that past epidemic control measures in Nigeria were not sustained, with little or no emphasis on preparedness. There should be a change in the past strategies employed by the health authorities. There is a need to establish a multi-sectoral epidemic preparedness team to create an enabling environment for managing epidemic alert and response as well as evaluating prevention and control, measures. Recommendations for the roles and responsibilities and modes of operation of such preparedness team were also made.
\end{abstract}

Key words: Lassa fever, Preparedness, Epidemics, Nigeria, Prevention and control.

Correspondence author:Adebimpe WO., Email: lekanadebimpe@gmail.com

Department of Community Medicine, College of Health Sciences, Osun State University, Osogbo Nigeria

Research Journal of Health Sciences subscribed to terms and conditions of Open Access publication. Articles are distributed under the terms of Creative Commons Licence (CC BY-NC-ND 4.0). (http://creativecommons.org/licences/by-nc-nd/4.0).

http://dx.doi.org/10.4314/wsa.v4i3.7 


\title{
Préparation pré-épidémique et le contrôle de la fièvre de Lassa au sud du Nigeria
}

\author{
Adebimpe Wasiu Olalekan
}

\begin{abstract}
Abstrait
L'épidémie de fièvre hémorragique virale (VHF) dans la région ouest-africaine dans la période récente a eu des conséquences négatives sur les systèmes de santé, voyages internationaux, les mouvements et les métiers. Le Nigeria est toujours aux prises avec un écart significatif de la fièvre de Lassa (LF) épidémie. Le pays ne semble pas avoir appris des épidémies passées surtout 2014 Ebola virus de la maladie (EVD) d'épidémie. Après la déclaration du Nigeria EVD libre, la plupart des arsenaux de contrôle ont été assouplies, les structures d'isolement et de quarantaine ont été démantelés et les efforts de prévention telles que la fourniture d'équipements de protection personnels (EPI) pour l'utilisation des travailleurs de la santé vulnérables ne sont pas soutenus.

Plusieurs moteurs de recherche ont été utilisés dans la navigation sur Internet tout en recherchant des littératures et des revues systématiques sur l'épidémiologie et le contrôle de la fièvre de Lassa dans la sousrégion ouest-africaine, et se rétrécissant vers le bas la recherche au Nigeria. Cet avis a présenté les résultats des épidémies passées de fièvre de Lassa au Nigeria et les stratégies de contrôle adoptées, y compris un examen de plusieurs recherches sur le sujet. Auteur également présenté un cadre de l'épidémie de lutte contre la maladie de la fièvre de Lassa et d'autres FHV, conformément aux recommandations de l'OMS: On a observé que les mesures de contrôle de l'épidémie passée au Nigeria ne sont pas soutenus, avec peu ou pas l'accent sur la préparation. Il devrait y avoir un changement dans les stratégies passées employées par les autorités sanitaires. Il est nécessaire de mettre en place une équipe de préparation aux épidémies multi-sectorielle pour créer un environnement propice à la gestion d'alerte d'épidémie, ainsi que l'évaluation de la prévention et de contrôle, les mesures. Recommandations pour les rôles et les responsabilités et les modes de fonctionnement de ces équipes de préparation ont également été faites.
\end{abstract}

Mots clés: fièvre Lassa, la préparation, les épidémies, le Nigeria, la prévention et de contrôle.

Correspondance auteur:Adebimpe WO, Email:. Lekanadebimpe@gmail.com

Département de médecine communautaire, College of Health Sciences, Osun State University PMB 4494 Osogbo Nigeria 


\section{Background to Lassa Fever outbreaks}

The outbreak of Lassa Fever (LF) and Ebola Virus Disease (EVD) in the West African sub region in recent times is a testimony to a dire need for a strong epidemic preparedness system among member countries of the World Health Organization in the AFRO region. This requires that diseases be notified through a sustained disease surveillance and reporting system (WHO, 2006). Such disease surveillance system should adequately identify, define and recognize cases of illness on a timely and complete basis; and culminating into data driven forecast and advice on the trend of infections (WHO, 2009).

The implications of recent outbreaks of Viral Hemorrhagic Fevers on the health systems, international travels, movements and trades are enormous. This is more obvious with the changing epidemiological pattern being observed over the years. LF is among the diseases on the epidemic prone list being reported under disease surveillance and notification system (CDC, 1996). Poor sanitation, overcrowding, inadequate resources to manage cases, a weak health systems and most importantly poor epidemic preparedness underscored the need for greater understanding of these diseases and more effective control measures according to the WHO in 2000.

The last sporadic outbreak of Lassa fever in Nigeria was in 2012; until in October 2015 when significant human lives loss were recorded as a part of the ongoing epidemics. While EVD had been put under control in Nigeria and the country certified EVD free in late 2014, the country is still battling with a significant spread of Lassa fever infections. Some factors that could have contributed to this trend include a lengthy dry season, weak health system, and poor public enlightenment programme in both urban and rural communities where over $60 \%$ of the population resides (Kelly et al., 2003). Lassa fever had been crying for the type of huge attention given to the EVD outbreak including strong political will, leadership and effective coordination of both local and international control efforts.

\section{Rational for epidemic preparedness}

Nigeria seems not to have learnt from past epidemics most especially the 2014 EVD outbreak. After the declaration of Nigeria EVD free, most control arsenals were relaxed, isolation and quarantine structures were dismantled and preventive efforts such as provision of Personal Protective Equipments (PPE) were not sustained.
Lassa Fever had been with us in Nigeria since 1969 and is still regrettably being talked about with more frenzy today and with a high case fatality rate (Ajayi et al., 2013). The reason could be that old and current strategies deployed had been the same and ineffective. There should be a change in the past strategies employed by the health authorities, which has failed to stop the recurrence of these deadly zoonotic viral hemorrhagic fevers, rather than continue with the fire brigade methods of raising alarm, daily blowby-blow ministerial updates of deaths and sicknesses.

Another epidemic of EVD would have definitely taken Nigeria back to the pre-epidemic days whereas other epidemics are ongoing from time to time. Instead of sustaining the preparedness efforts and prepare for potential epidemics, Nigeria had been in the habit of panicking and citizens anxious during epidemics. Myth and misconceptions, excessive fear, neglect of humanitarian work, stigma and discrimination and poor awareness fuelled successive past epidemics in Nigeria (Adebimpe, 2015c). Despite popular outbreak of VHFs, and successes and intrigues surrounding their control efforts, Nigeria is not expected to be caught significantly in the web of mortality since the epidemiology and control of VHFs most especially LF and EVD are similar.

\section{Epidemiology of Lassa fever}

Lassa virus is the causative organism of Lassa fever infection. It is zoonotic and spreads to humans from rodents, specifically multimammate mice (Mastomys natalensis). (Healing, 2001; Richmond, 2003). These mice are ubiquitous in human households and are occasionally eaten as a delicacy in some areas (Richmond, 2003). Factors such as unplanned urbanization, indiscriminate refuse disposal, poor personal hygiene and overcrowded housing contribute to vector movements (Hala, 2013). Human to human transmission is not uncommon. Lassa fever is a viral hemorrhagic fever in West Africa (Frame, 1970) following its discovery in Northern Nigeria in 1969. The virus accounts for up to half a million cases of Lassa fever per year in West Africa, with about 5,000 resulting in deaths (Ogbu, 2007). Reported prevalence of Lassa Virus antibodies in the general population was $8-52 \%$ in Sierra Leone (Gonzalez et al., 2007), 4-55\% in Guinea (Gonzalez et al., 2007), and $21 \%$ in Nigeria (Ogbu, Ajuluchukwu and Uneke, 2007). During LF outbreaks, the casefatality rate could reach as high as $50 \%$ 
(Gershman, 2015; Rainisch et al., 2014 and Nadezhda and Walker, 2012). LF has an overall fatality rate of $1-2 \%$; much lower than the fatality rate of $9.3 \%$ to $18 \%$ seen among all hospital admissions (Nadezhda and Walker, 2012, Kay and Baglole, 2003) or 1-15\% (WHO, 2005). Several imported cases with hazardous outcomes had been reported in countries where it is not endemic (Bowen et al., 2000; Atkin et al., 2009)

In Nigeria, a survey of the 2012 epidemic reported viral detection in 25 of 60 (42\%) patients in northern and central Edo State which is a hotspot for the disease in recent times, affecting adults and children alike (Ehichioy, 2012).

The 2012 LF outbreak was controlled through effective coordination, laboratory testing, active surveillance, community mobilization, contact and suspected case evaluation, and case management. In another study assessing the 2012 epidemic (Ajayi et al, 2013), high fatality, nosocomial transmission and poor public sensitization characterized the epidemic. The lessons learnt from these scenarios underscored the need for effective epidemic and emergency preparedness in order to implement these measures on a regular scale. The ongoing epidemic of late 2015 and 2016 could be summarized according to the figure below, thus portraying the ongoing scenario as highly prevalent and requiring urgent attention.

\section{Framework for LF epidemic control}

Based on the epidemiology and the natural history of LF, it is possible to formulate a framework of epidemic disease control for Lassa fever and other VHFs in Nigeria. In line with WHO recommendations (WHO, 2014), the cycle of efforts to be carried out could be divided into four namely: preparedness, alert creation, control and containment measures and post epidemic evaluation. The epidemic preparedness component provides the solid ground for the other three components as it determines how well the health and social services systems would respond to outbreak. The success or otherwise of control measures would be determined by the extent to which the host country can harness local resources and put it into effective use; i.e the strength of the preparedness of the host country towards alert creation and institution of control measures.

Despite the delegation of Nigeria as the regional center for disease control in West Africa and the success of the EVD control in 2014, there is a need to have a strong health system and epidemic preparedness system on ground to watch over and prepare for future VHF epidemics and work towards control.

\section{Recommendations for general LF control (1) Establishment of regional; and country epidemic preparedness team}

There is a need for every country level institution or committee that would coordinate preparedness, detection and timely response to public health emergencies, and working with international partners. Nigerian should fix into a regional cooperation and international partnerships, as well as inter-country teams for the surveillance program: Though communicable disease epidemiology varies widely within the Africa region, yet similarities often exist between neighboring countries and within countries. Standardization of policies, tools, or procedures among countries with similar epidemiological profiles can increase response effectiveness.

In addition, epidemics can quickly spread across borders, and prompt exchange of information from one country to the other can increase the timeliness and effectiveness of interventions. A sub-regional organization specialized in epidemic preparedness and response could facilitate the exchange of information even within regions. Geo-political or State based preparedness team in the case of Nigeria could provide response in the form of emergency preparedness, ensure fast protection of lives and reduction of vulnerability and saving lives when an outbreak occurs. The author is not aware of the existence of a sustained epidemic preparedness team in Nigeria, charged with the role and responsibilities of preparing and responding to epidemic alerts

\section{(2) Strong political will}

One of the lessons learnt from EVD containment in Nigeria was the willingness of Government towards ending the epidemic. Government provided strong leadership and coordinated control efforts. There should be a budget line available for emergency response, though such funding is yet to enter the 2016 national budgets despite the significance of this disease. The ongoing LF epidemic in Nigeria is thus begging for similar political commitment as given to EVD in year 2014. Enforcement of some health provisions would require strong political will on the part of the Government. Nigerians are not used to some public health methodologies such as isolation, limitation of movements and tracking of contact persons (Haas et al., 2003). These concepts require legal backing as well as 
the enforcement of some legislation, in case there are some levels of resistance from individuals or groups.

\section{(3) Establishment of effective disease notification and prompt action system}

Timely and accurate reporting is an important component of communicable disease control efforts. With the epidemic preparedness task force in place, it is their duty to identify factors influencing the changing epidemiology of Lassa fever, and forecast all possible disease escalating factors towards making country or regional level recommendations including taking actions. To showcase poor practice of surveillance among health personnel, Bawa, Olumide and Umar in 2003 studied 144 health personnel from 88 health facilities, only fifty-five $(38.2 \%)$ of the respondents were aware of the national Disease Surveillance and Notification (DSN) system. Their mean score regarding immediate notifiable diseases was $0.8+/-1.23$ SD (maximum of 10$)$. Thirty nine $(70.9 \%)$ reported to have ever reported, while $16(29.1 \%)$ have never reported any of the notifiable conditions. Only $12(21.8 \%)$ of the respondents claimed to have ever received feedback on the reports they forwarded to higher authorities and more than $92 \%$ of the health facilities lacked the DSN 001 and 002 forms. Most of the respondents $47(85.5 \%)$ that were aware of the reporting requirements listed lack of training on disease surveillance as one of the factors affecting disease reporting. This shows that lack of knowledge of reporting requirement was identified as a major factor affecting disease surveillance among the respondents.

In another related study, Aniwada1 and Obionu, 2016 found out that some of the factors associated with reporting type of health facilities included; correct definition of IDSR (AOR $=2.6$, 95\% CI: 1.4-5.1), correct knowledge of diseases reported $(\mathrm{AOR}=4.1,95 \% \mathrm{CI} 2.1-8.0)$, correct place to report to $(\mathrm{AOR}=3.7,95 \%$ CI $1.9-7.2)$, correct form for monthly reporting $(\mathrm{AOR}=7.0$, 95\% CI 3.5-14.0), ever reported occurrence of disease $(\mathrm{AOR}=8.5,95 \% \mathrm{CI} 4.0-18.2)$, reporting in correct place $(\mathrm{AOR}=11.5,95 \% \mathrm{CI} 1.8-73.6)$, current availability of forms at facility $(\mathrm{AOR}=$ $4.9,95 \%$ CI 2.5-9.5), supervision or data collection visits $(\mathrm{AOR}=8.8,95 \% \mathrm{CI} 4.3-18.1)$ and regularity of the visits $(\mathrm{AOR}=6.4,95 \% \mathrm{CI}$ 2.3-17.6). It was concluded that disease surveillance and notification needs to be improved on especially in areas of manpower training and regular supply of forms for efficient
Health Management Information System and containment of most diseases ravaging the nation.

\section{(4) Stepping up focused epidemiologic research}

There is a need to encourage health institutions to conduct more applied research that would produce newer drugs and vaccine Currently there are no vaccines or antiviral drugs specifically approved for Lassa fever. Treatment with intravenous Ribavirin with its complex pharmacokinetics was shown to be promising in terms of mortality and morbidity reduction most especially if initiated within the first week of disease onset (McCormick et al, 1986). Early attempts to develop a vaccine against Lassa fever focused on classical approaches such as killed vaccines. A whole-virion vaccine inactivated by gamma irradiation provided a good humoral response to Lassa viral proteins, NP, and GP had been tried, but failed to protect nonhuman primates from a lethal Lassa challenge (McCormick et al., 1992). There is a need to conduct more vaccine trials, similar to the numerous and concerted efforts put into getting a vaccine for the EVD epidemic. The preparedness team could encourage governments at all levels to fund individual and group research towards newer drugs and vaccine development.

\section{(5) Public enlightenment on personal hygiene}

Since the vector of Lassa fever are commonly found in households, and which can easily contaminate grains and other food items, it is necessary for stakeholders to organize and sustain public health enlightenment sessions on LF. This was one of the reasons for the successful containment of EVD outbreak with national governments providing leadership towards this course. Creating better awareness would encourage behavioural change that would lead to effective control.

In a community based study conducted in southwestern Nigeria, (Adebimpe, 2015a), only $14.1 \%, 17.0 \%$ and $13.9 \%$ of respondents had good knowledge of occurrences, causes, disease transmission, and prevention and control of LF respectively, 215 participants $(43.0 \%)$ lived in overcrowded rooms and only 36(9.1\%) claimed to never have seen a rat in their houses. Reviewing several studies, rate of awareness of LF include $87 \%$ of the respondents (Reuben and Gyar, 2016), 82.2\% from Owo, Ondo State, Nigeria (Olayinka et al. 2015) and $93.1 \%$ in Irrua (an endemic area) among households in Edo 
State, Nigeria (Ochei et al. 2014). The high awareness figures reported in these studies could be because they were all hotspots for LF outbreaks; and high sensitization and awareness campaign would have been given to the disease during past epidemics.

In a community based study (Adebimpe et al., 2015) the culture of regular handwashing has not drastically improved despite the 2014 EVD outbreak and during which handwashing was taken as a necessary ritual, and handwashing basins prepared for schools, industries, institutions and even the communities.

In another community based study carried out in Nigeria (Adebimpe, 2015b), 40.2\% of households were found to have a separate store for loads and food items, while about $21 \%$ said their food items such as grains were freely exposed or not in closed plastic containers, amidst daily accumulation of refuse among $59.2 \%$ of households studied..Public enlightenment could foster behavioural change among community members once they know the implication of being at environmental risk of contracting and dying from Lassa fever infection. The epidemic preparedness team should be decentralized in order to implement and sustain these health promotion efforts.

A community based study showed that literate and illiterate rural dwellers irrespective of gender had no awareness of rat as vector of Lassa fever (Adefisan, 2014) Myths and misconceptions fuelled the ongoing VHFs including LF epidemics, leading to unnecessary fears among the public and refusal of health care workers to take up humanitarian jobs for fear of being infected. (Adebimpe, 2015c).. The media, and indeed the social media is a veritable way of spreading health education (Adebimpe et al., 2015) about VHF most especially the educated community members who also have access to the social media.

Stigma and discrimination appears to be slowing down the effectiveness of public health education as an important component of prevention of Lassa fever. In a related study (Reuben and Gyar, 2016), $41 \%$ of the respondents would show some discriminatory attitudes towards infected individuals whereas $35.5 \%$ will keep the information secret if a family member is suspected to be infected with LF. Whereas $71 \%$ agreed that individuals diagnosed with LF must be admitted in LF treatment centre, 29\% agreed that those tested positive for LF must be quarantined for some weeks. Though risk perception among a studied community was reported as fairly good (Adebayo, 2015) the role of sustained health education using appropriate methods cannot be over-emphasized (Inegbenebor, Okosun and Inegbenebor J2010).

\section{(6) Strengthening Integrated Disease Surveillance and Response (IDSR)}

Not just DSN: Lassa fever had been on the list of epidemic prone diseases to be notified in Nigeria. However there are several challenges to the disease notification process and most efforts were not integrated. Presently, the existing surveillance system is insensitive as it is incapable of detecting early warning signs of outbreaks. The resultant effect of the poor surveillance system is high mortality, morbidity and disability, with attendant suffering of the people. Most DSN challenges still subsists in Nigeria, including funding, laboratory, poor reporting, communication problems, vertical programmes doing parallel reporting.

In a related study (Nnebue et a;., 2012) reported that although $89.8 \%$ of the health-care workers were aware of the DSN system, only $33.3,31.1$, and $33.7 \%$ of them knew the specific uses of forms IDSR 001, IDSR 002, and IDSR 003 (IDSR: Integrated Diseases Surveillance and Response), respectively. Knowledge of use of the various forms at the facility and local government area (LGA) levels were generally low, although the observational checklist revealed that IDSR 001 and IDSR 002 forms were predominantly found in primary health-care facilities. HMIS forms were less likely to be available in secondary health-care facilities $\left(\chi^{2}=7.67\right.$, $P=0.005$ ).

\section{(7) Building a strong health system}

There is a need to have a battle ready health workforce that is prepared to respond to (emergency) mobilization towards control of outbreaks of Lassa fever. In Nigeria, awareness of LF among health workers is still low in some areas and high in some. Clinicians could continue with malaria treatments as a response to the usual treatment of fevers, thus making clients to present late.

In a study among HCWs (Adebimpe, 2015b), $67.7 \%, 63.0 \%, 61.2 \%$ and $56.0 \%$ had good knowledge of occurrences, causes, disease transmission and prevention and control of LF respectively. Only 20(6.7\%) of the health care workers had ever reported a suspected case of LF before, $63(21.0 \%)$ regularly used protective gadgets at work. Predictors of good awareness of LF include being a male, ever reported a case of 
LF and regular use of protective gadgets at workplace.

In another study among $\mathrm{HCW}$ (Idris,Inem and Balogun, 2015), proportion of respondents with good knowledge and practice among public HCWs was $98.5 \%$ and $93.8 \%$; and among private $\mathrm{HCW}, 95.9 \%$ and $89.7 \%$. Proportion of respondents with positive attitude was $67 \%$ (public) and $72.7 \%$ (private).

Ogoina et al., 2015 in a Nigerian study found an overall median knowledge and attitude scores of health care workers toward standard precautions to be above $90 \%$, but median practice score was $50.8 \%$. The majority of the HCW had poor knowledge of injection safety and complained of inadequate resources to practice standard precautions. House officers, laboratory scientists and junior cadres of nurses had lower knowledge and compliance with standard precautions than more experienced doctors and nurses

In another study, $95 \%$ of studied health workers were aware of LF (Tobin et al., 2013), though overall knowledge of Lassa fever was poor for $51(38.9 \%)$, and fair for $54(41.2 \%)$ and good for 260 (19.8\%). While awareness may not necessarily translate into knowledge as seen in this study, the apparently higher levels of awareness may be due to the greater attention given to public sensitization. There is a need to train and retrain HCWs generally along that line and encourage them to have a high index of suspicion for VHFs. Patients should be placed in a single room (containing a private bathroom) with the door closed.

(8) Universal precaution and use of personal protective equipment (PPE):

Health-care provider protection: One of the cornerstones of standard precautions which offer a consistent approach to infection control is the appropriate use of personal protective equipment (PPE) whenever contact with blood or body fluids is anticipated (Hinkin J, Gammon J, 2008) Compliance with these standard precautions has been shown to reduce the risk of exposure to blood and body fluids (Amoran and Onwube, 2013), In a study (Amoran and Onwube,, 2013), , a total of $421 \mathrm{HCWs}$ were interviewed, Majority (77.9\%) correctly describe universal precaution and infection control with 19.2, 19.2, and 28.0\%, respectively unable to recognize vaccination, post-exposure prophylaxis, and surveillance for emerging diseases as standard precaution for infection control. About $70.1 \%$ usually wear gloves before handling patients or patients' care products, $12.6 \%$ reported wash their hand before wearing the gloves, $10.7 \%$ washed hands after removal of gloves, and $72.4 \%$ changed gloves after each patient. Only $3.3 \%$ had a sharp disposal system in their various workplaces. Majority $(98.6 \%)$ of the respondents reported that the major reason for non-compliance to universal precautions is the non-availability of the equipments. However, systematic reviews of compliance with the use of PPEs as infection control measures had been rated as low to poor (Mbanya et al., 2001; Newsom and Kiwanuka, 2002; Nsubuga and Jaakkola, 2005; Orji et al., 2002; Reis et al., 2005; Sadoh et al, 2006; Talashek et al., 2007; Walusimbi and Okonsky, 2004).

Health-care providers should regularly wear gloves (fluid resistant or impermeable), shoe covers, eye protection (goggles, face shield), and face mask. Poor availability and inadequate supply of PPEs in health facilities, and poor and inconsistent use of PPEs among health care workers is another challenge facing LF control, as reported by some studies (Ajayi et al., 2013, Aigbiremolen et al., 2012). In another meta-analysis of the use of PPE among health care workers featuring thirty non-comparative studies, reporting of personal protective equipment components and infection prevention and control protocols was generally poor (Hersi, 2015). In another related study (Schwartz , Shapira and, Bar-Dayan , 2014), PPE confidence was higher among HCWs with higher tested and self-perceived knowledge. Confidence was also higher among nurses compared with physicians and among employees in hospitals compared with those in primary care clinics.

In relation to special knowledge of its use, additional PPE might be required in a certain situation (e.g. copious amount of blood being vomited, other body fluids, or feces present in the environment), including double gloving, disposable shoe covers and leg coverings. In a study among HCWs (Chia et al., 2005; Adebimpe, 2015b), one of the predictors of good awareness of LF include a regular use of protective gadgets at workplace.

\section{(9) Improved International Health Regulations and port health services}

With the world gradually becoming a one global village, infectious disease could easily be imported from a foreign to a host country, made possible by international travels and movements. It is important that international health regulations be followed strictly by government 
authorities and health concerns, disease surveillance and screening be given priority at the entry points most especially seaports and airports all in a bid to prevent communicable disease spread.

Laboratory networking: Definitive diagnosis of LF in the laboratories requires molecular testing that is available only in highly specialized laboratories. Lassa fever is diagnosed by detection of Lassa antigen, anti-Lassa antibodies, or virus isolation techniques. The proportions of health facilities that have ELIZA machines are numbered. These can only prolong the turn around time of results from laboratories to clinicians or the community where they are needed.

\section{(10) Community rodent control}

Since the vector of LF is found in the community, it is important to eliminate the vectors and prevent human-vector contacts as much as possible, putting into cognizance the preventable and controllable environmental vector thriving factors such as poor refuse disposal, poor attitude to fumigation activities and poor personal and environmental hygiene.

In a community based study (McCormick et al., 1987), Mastomys natalensis, the reservoir of Lassa virus, constituted $50 \%-60 \%$ of the rodents captured in houses but only $10 \%-20 \%$ of those captured in surrounding agriculture and bush areas (chi $2=90.2$, P less than $10(-6)$, $\mathrm{df}=1$ ), a finding suggesting that houses are the mostimportant location for transmission of Lassa virus. In another community based study conducted in southwestern Nigeria, only 36 $(9.1 \%)$ claimed to never have seen a rat in their houses. 277 participants $(55.4 \%)$ said that rats moved freely in their houses, while 206 (41.2\%) reported that they often saw rats cross between houses (Adebimpe, 2015a).

In another study (Reuben and Gyar, 2016), majority $(83 \%)$ of the respondents; $82.6 \%$ and $84.4 \%$ from urban and sub-urban areas indicated the presence of rats and other rodents in and around their residence. Some of the respondents $24 \%, 28 \%$ and $33 \%$ feed on food contaminated by rodents, come in contact with urine/faeces/other products of rodents and consume rodents.

\section{Epidemic preparedness strategies}

The first step in pre-epidemic preparedness is to set up the surveillance and response team towards stepping up routine surveillance of LF and other VHFs. This multi-sectoral epidemic management committees and rapid response teams-would have to meet monthly in order to be epidemic ready. The team should be replicated at the state or regional level, with the national team coordinating. Relevant sectors include health, veterinary health and agriculture, environment, housing, education among others. A breakdown of preparedness efforts to be carried out by the national or regional team includes:

1. Obtain national and regional standard case definitions as in the in-country IDSR guidelines. This could form the basis of sensitizing HCWs and their disease reporting activities.

2. Train and re-train HCWs in active surveillance and commencement of special surveillance efforts during epidemic alerts. They are to commence regular community based surveillance and identify supportive community structures. They are also to create a system for the collection, packaging, storage, and shipment of laboratory specimens

3. Implement standard infection control policies and guidelines in health-care settings through training on infection control procedures, bio-safety standards and supply of PPEs and other supplies needed for epidemiological investigation at the district, state, regional and national levels

4. Improve health-related behaviours among at-risk and vulnerable groups through trainings, sensitization and public or community awareness

5. Encourage collaboration between veterinary services and public health authorities' thereby encouraging environmental control of rodents and other vectors within the communities. These include fumigation, proper cooking of animals being used for meats and roasted animals in the rural areas.

6. In preparatory for the alert phase upon suspecting an outbreak, the preparedness team should conduct a comprehensive awareness-raising, social mobilization campaign focusing on promoting specific risk reduction and health protection behaviours. The Television, the print media, and public health campaigns and enlightenment programmes are veritable ways of achieving this aims and objectives. This public sensitization efforts would not 
only douse tension associated with myths and misconceptions during outbreak but also allays fears of people, discourages states from denying cases identified within their territories, encourage $\mathrm{HCWs}$ and other social workers in taking part in health humanitarian work and foster community rodent control. The use of government agencies such as the Nigeria's National Orientation Agency (NOA) and the Child - to - Child (CTC) health initiative are examples of programmes that could create a platform for this sensitization activities.

7. The team should also assess the extent of local resources available to respond to a epidemic alert. Such assessment should include laboratory equipments pretesting, availability of relevant laboratory reagents, the readiness of the health resources available for field work, the mindset and preparedness of the local media, and funds available in the national budget for general and emergency disease control. The team need to carry out geographical and epidemiological mapping of all states and communities that are hotspots for LF outbreaks, and laying more surveillance on these areas with a view to early suspicion and reporting of cases of Lassa fever disease.

\section{CONCLUSION}

Past epidemic control in Nigeria have occurred, leaving little or no traces of existing control structures behind and preparing no ground for future outbreaks, and little or no emphasis on preparedness. There should be a change in the past strategies employed by the health authorities. There is a need to establish a multi-sectoral team to assess the extent of local resources available to respond and manage epidemic alert and response as well as evaluating prevention and control, measures. There is a need to encourage more local applied research on Lassa Fever and EVD outside the usual Knowledge, Attitude and Practice platforms.

\section{Conflicts of interest: None declared}

Acknowledgement: The author wish to thank the Lassa Fever monitoring team of the Association of Public Health Physicians of Nigeria (APHPN), for the use of the alert figures on the ongoing LF epidemic in Nigeria.

\section{REFERENCES}

1. Adebayo, D, Nwobi, E.A, Vincent, T, Gonzalez, J.P (2015). Response Preparedness to Viral Hemorrhagic Fever in Nigeria: Risk Perception, Attitude towards Lassa Fever. Epidemiology (sunnyvale) 5:199.

2. Adebimpe, W.O (2015a). Community awareness and perception towards rodent control: implications for prevention and control of Lassa fever in urban slums of southwestern Nigeria. Malta Journal of Health Sciences, $3: !: 26-32$

3. Adebimpe, W.O (2015b). Knowledge and preventive practices against Lassa fever among primary health care workers in Osun state. University of Mauritius Medical Journal, 21:579-593

4. Adebimpe, W.O (2015c). From a single case to epidemics: Fear and misconceptions mitigating against effective control of Ebola virus disease outbreak in South-Western Nigeria. Niger J Health Sci, 2015;15:589.(Letter to the Editor)

5. Adebimpe WO, Bamidele JO, AsekunOlarinmoye EO and Abodunrin OL(2012). Awareness and attitude of health care workers in a teaching hospital in southwestern Nigeria towards Nosocomial infections. Journal of Public Health and Epidemiology, 4(10) 285289

6. Adebimpe, W.O, Adeyemi, D.H, Faremi A, Ojo JO, Efuntoye AE (2015). The relevance of the social networking media in Ebola virus disease prevention and control in Southwestern Nigeria. Pan Afr Med J. 22 (Supp 1):7: 1-4

7. Adefisan, A.K.(2014). The Level of Awareness that Rat is a Vector of Lassa Fever among the Rural People in Ijebu-North Local Government, Ogun State, Nigeria. Journal of Education and Practice,.5 (37): 166-173

8. Aigbiremolen, A.O, Duru, C.B, Awunor, N.S, Abejegah, C, Abah, S.O, Asogun, A.D, (2012). Knowledge and application of infectious disease control measures among primary care workers in Nigeria: the Lassa fever example. International Journal of Basic, Applied and Innovative, Research. IJBAIR, 1(4): $122-1$

9. Ajayi, N.A, Nwigwe, C.G, Azuogu, B.N, Onyire, B.N, Nwonwu, E.U, Ogbonnaya, L.U et al (2012). Containing a Lassa fever epidemic in a resource-limited setting: outbreak description and lessons learned from Abakaliki, Nigeria, Int J Infect Dis. 2013 Nov;17(11):e1011-6. 
10. Amoran, O.E and Onwube, O.O.(2013) Infection Control and Practice of Standard Precautions Among Healthcare Workers in Northern Nigeria. J Glob Infect Dis, Oct-Dec; 5(4): 156-163.

11. Aniwada1, E.C and Obionu, C.N.(2016). Disease Surveillance and Notification, Knowledge and Practice among Private and Public Primary Health Care Workers in Enugu State, Nigeria: A Comparative Study, BJMMR, 13(3): 1-10.

12. Atkin,, S, Anaraki, S, Gothard, P, Walsh, A, Brown, D. (2009). The first case of Lassa fever imported from Mali to the United Kingdom, Euro.Surveill.14:2-4.

13. Bawa, S.B, Olumide, E.A, Umar, U.S. (2003). The knowledge, attitude and practices of the reporting of notifiable diseases among health workers in Yobe State, Nigeria. Afr J Med Med Sci, 32(1):49-53.

14. Bowen, M.D, Rollin, P.E, Ksiazek, T.G, Hustad, H.L, Bausch, D.G. (2000). Genetic diversity among Lassa virus strains. J. Virol. 74: 6992-7004.

15. Centre for Disease Control: Comprehensive plan for emergency surveillance. Atlanta, Georgia, 1996. In: Last JM editor. A dictionary of Epidemiology $4^{\text {th }}$ ed. London: Oxford University Press; 2001: 174-5

16. Chia, S.E, Koh, D, Fones, C, Qian, F, Ng, V, Tan, BH et al. (2005). Appropriate use of personal protective equipment among healthcare workers in public sector hospitals and primary healthcare polyclinics during the SARS outbreak in Singapore. Occup Environ Med., 62(7):473-7.

17. Ehichioya, D. U, Asogun, D. A, Ehimuan, J, Okokhere, P. O, Pahlmann, M, Ölschläger, S, et al.,(2012). "Hospital-based surveillance for Lassa fever in Edo State, Nigeria, 2005-2008". Tropical Medicine \& International Health 17 (8): 1001-1004.

18. Frame, J.D, Baldwin, J.M, Gocke, D.J, Troup, J.M (1970). "Lassa fever, a new virus disease of man from West Africa. I. Clinical description and pathological findings". Am. J. Trop. Med. Hyg. 19 (4): 670-6.

19. Gershman, M.D, Staples, J.E (2015) Infectious Diseases Related to Travel: Yellow Fever. In: Brunette GW, edtn. CDC Health Information for International Travel. New York: Oxford: 78.

20. Gonzalez, J.P, Emonet, S, de LamballerieX, Charrel R (2007) Arenaviruses. Curr Top Microbiol Immunol 315:253-88.

21. Haas, W.H, Breuer, T, Pfaff, G, Schmitz, H,
Kohler, P, Asper, M et al (2003). Imported Lassa fever in Germany: surveillance and management of contact persons. Clin. Infect. Dis. 36:1254-1258.

22. Hala, I.A. (2013) Health effect of slums: A consequence of urbanization. Scholarly Journal of Medicine,3 (1) pp.7-14.

23. Healing T, Gopal R. Report on an assessment visit to Sierra Leone, April 12th-30th 2001. London: Merlin, 2001.

24. Hersi, M, Stevens, A, Quach, P, Hamel, C, Thavorn, L and Garritty, C. (2015). Effectiveness of Personal Protective Equipment for Healthcare Workers Caring for Patients with Filovirus Disease: A Rapid PLoS One, 10(10): e0140290.

25. Hinkin, J, Gammon, J, Cutter, J. (2008). Review of personal protection equipment used in practice. Br J Community Nurs, 13(1):14-9.

26. Idris, B.I, Inem, V and Balogun, M (2015). Comparing the knowledge, attitude and practices of health care workers in public and private primary care facilities in Lagos State on Ebola virus disease. Pan Afr Med J, 22(Suppl 1): 19 .

27. Inegbenebor, U, Okosun, J, Inegbenebor, J. (2010).Prevention of lassa Fever in Nigeria. Trans R Soc Trop Med Hyg., 104(1):51-4.

28. Kay, R.J, Baglole, D.J(2003)

29. Kelly, J.D, Barrie, M.B, Ross, R.A, Temple, B.A, Moses, L.M, Bausch, D.G (2003). Housing equity for health equity: a rights based approach ti the control of Lassa fever in post war Sierra Leone.. BMC International Health and Human Rights. 13:2 doi:10.1186/1472698X-13-2

30. Mbanya, D.N, Zebaze, R, Kengne, A.P, Minkoulou, E.M, Awah P, Beure, S (2010). Knowledge, attitudes and practices of nursing staff in a rural hospital of Cameroon: How much does the health care provider know about the human immunodeficiency virus/acquired immune deficiency syndrome? Int Nurs Rev, 48:241-9. [

31. McCormick, J.B, Webb, P.A, Krebs, J.W, Johnson, K.M, Smith, E. S.(1987). A prospective study of the epidemiology and ecology of Lassa fever. Infect Dis, 155(3):43744.

32. McCormick, J.B, King, I.J, Webb, P.A, Scribner, C.L, Craven, R.B (1986). Lassa fever. Effective therapy with ribavirin. N Engl J Med 314: 20-26.

33. McCormick, J.B, Mitchell, S.W, Kiley, M.P, Ruo, S, Fisher-Hoch, S.P (1992) Inactivated Lassa virus elicits a non protective immune 
response in rhesus monkeys. J Med Virol 37: $1-7$.

34. Nadezhda, E.Y, Walker, D.H (2012) Pathogenesis of Lassa Fever. Viruses 4:20312048.

35. Newsom, D.H, Kiwanuka, J.P. (2002).Needlestick injuries in an Ugandan teaching hospital. Ann Trop Med Parasitol, 96:517-22.

36. Nnebue, C.C, Onwasigwe, C.V, Adogu, P.O and Onyeonoro, U.U. (2012).Awareness and knowledge of disease surveillance and notification by health-care workers and availability of facility records in Anambra state, Nigeria. Niger Med J, 53(4): 220-225.

37. Nsubuga, F.M, Jaakkola, M.S. (2005).Needlestick injuries among nurses in sub-Saharan Africa. Trop Med Int Health, 10:773-81.

38. Ochei, O, Abejegah, C, Okoh, E, Abah, S.O. (2014). Housing Factors and Transmission of Lassa Fever in a Rural Area of South-south Nigeria. Gen. Heal. Med. Sci. 1(2): 15-20

39. Ogbu O, Ajuluchukwu E, Uneke C.J (2007) Lassa fever in West African sub-region: an overview. J Vect Borne Dis 44:1-11.

40. Ogoina, D, Pondei, K, Adetunji, B, Chima, G, Isichei, C and Gidado, S.(2015). Knowledge, attitude and practice of standard precautions of infection control by hospital workers in two tertiary hospitals in Nigeria Journal of Infection Prevention, 16(1) 16-22

41. Olayinka, S.I, Omotoso, B, Osaretin, A.F, Adewuyi, F. (2015). Awareness of Lassa Fever in a Rural Community in South West Nigeria. Sch. J.Appl. Med. Sci. 3(3B):1137-1142

42. Orji, E.O, Fasubaa, O.B, Onwudiegwu, U, Dare, F.O, Ogunniyi, S.O.(2002). Occupational health hazards among health workers in an obstetrics and gynaecology unit of a Nigerian teaching hospital. J Obstet Gynaecol, 22:75-8.

43. Rainisch, G, Shankar, M, Wellman, M, Merlin, T, Meltzer M.I (2015) Regional spread of Ebola virus, West Africa 2014. Emerg Infect Dis 21:444-7.

44. Reuben, C.R, Gyar, S.D. (2016). Knowledge, attitudes and practices of Lassa fever in and around Lafia, Central Nigeria. International Journal of Public Health and Epidemiology Research, 2(1): 014-019.

45. Reis, C, Heisler, M, Amowitz, L.L, Moreland, R.S, Mafeni, J.O, Anyamele, C, et al(2005). Discriminatory attitudes and practices by health workers towards patients with HIV/AIDS in Nigeria. PLos Med, 2:e246.

46. Richmond, J. K.; Baglole, D. J. (2003). . BMJ 327 (7426): 1271-1275.
47. Sadoh, W.E, Fawole, A.O, Sadoh, A.E, Oladimeji, A.O, Sotiloye, O.S. (2006). Practice of universal precautions among healthcare workers. J Natl Med Assoc, 98:722-6.

48. Schwartz, D, Shapira, S, Bar-Dayan, Y.(2014). Health Care Workers' Knowledge and Confidence in Personal Protective Equipment During the H1N1 Pandemic in Israel. Disaster Med Public Health Prep, 11:1-8.

49. Talashek, M.L, Kaponda, C.P, Jere, D.L, Kafulafula, U, Mbeba, M.M, McCreary, L.L, et al(2007). Identifying what rural health workers in Malawi need to become HIV prevention leaders. J Assoc Nurses AIDS Care, 18:41-50.

50. Tobin, E.A, Asogun, D.A, Isah, E.C, Ugege, O.G, Ebhodaghe, P. (2013). Assessment of knowledge and attitude towards Lassa fever among Primary care providers in an endemic suburban community of Edo state: implications for control. J. Med. Medic. Sci. 4(8): 311-318.

51. WHO. (2014) Ebola and Marburg virus disease epidemics: preparedness, alert, control and evaluation August 2014, Page 19, available at www.who.int.ebola/factsheet/en. Accessed December 2015..

55. WHO(2009). Communicable Disease Surveillance and Response (CSR): Available $\begin{array}{lllll}\mathrm{f} & \mathrm{r} & \mathrm{O} & \mathrm{m}\end{array}$ http://www.who.int/emc/surveill/index.html [Last accessed on 2016 December 19]

56. Walusimbi, M, Okonsky, JG.(2004). Knowledge and attitude of nurses caring for patients with HIV/AIDS in Uganda. Appl Nurs Res, 17:92-9.

57. World Health Organization (WHO) Lassa fever fact sheet No 179. Geneva: WHO, 2000.

58. World Health Organization (2006). International Health Regulations and global infectious disease surveillance, Geneva: WHO, 2006 


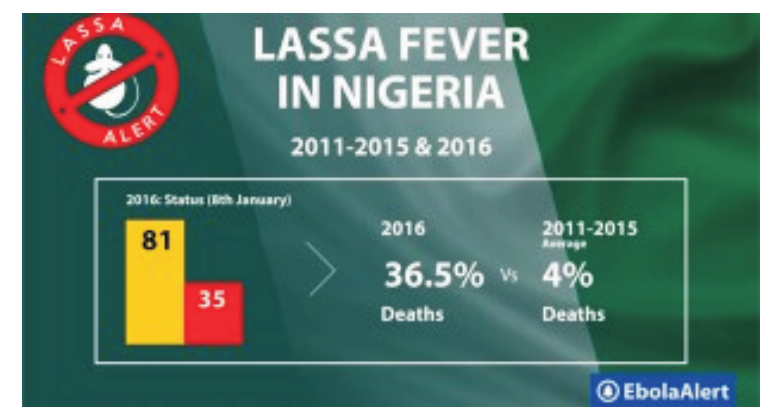

Figure 1: Magnitude of the 2016 ongoing Lassa fever outbreak in Nigeria (January $30^{\text {th }}$ ) courtesy APHPN monthly alert on Lassa fever

Table 1: Framework for Lassa fever preparedness and control.

\begin{tabular}{|c|c|c|c|}
\hline Preparedness & Alert & Control & Evaluation \\
\hline $\begin{array}{l}\text { Establish preparedness } \\
\text { and response team }\end{array}$ & $\begin{array}{l}\text { Investigation of } \\
\text { epidemics }\end{array}$ & $\begin{array}{l}\text { Implement control } \\
\text { strategies }\end{array}$ & Prepare report \\
\hline $\begin{array}{l}\text { VHF surveillance } \\
\text { systems, and assess } \\
\text { local resources needs }\end{array}$ & $\begin{array}{l}\text { Specimen } \\
\text { transport and } \\
\text { shipment }\end{array}$ & $\begin{array}{l}\text { Coordination, political } \\
\text { will and strong } \\
\text { leadership }\end{array}$ & $\begin{array}{l}\text { Commence and } \\
\text { continue } \\
\text { preparedness efforts }\end{array}$ \\
\hline $\begin{array}{l}\text { Infection control } \\
\text { precautions }\end{array}$ & $\begin{array}{l}\text { Assess local } \\
\text { resources and } \\
\text { needs }\end{array}$ & $\begin{array}{l}\text { Case management } \\
\text { Surveillance } \\
\text { continuous }\end{array}$ & Keep records \\
\hline $\begin{array}{l}\text { Health promotion } \\
\text { programmes }\end{array}$ & $\begin{array}{l}\text { Interprete lab } \\
\text { results }\end{array}$ & $\begin{array}{l}\text { Circumvent logistics } \\
\text { Social interventions }\end{array}$ & $\begin{array}{l}\text { Continue social } \\
\text { interventions }\end{array}$ \\
\hline $\begin{array}{l}\text { Collaboration with } \\
\text { animal health services }\end{array}$ & Take actions & $\begin{array}{l}\text { Media } \\
\text { Environment }\end{array}$ & $\begin{array}{l}\text { Evaluate outbreak } \\
\text { management }\end{array}$ \\
\hline
\end{tabular}

